\title{
Assessment of food safety conditions at food service premises using Thai survey form and field fecal indicator testing in Pakpoon municipality of Nakhon Si Thammarat, Thailand
}

\author{
Apirak BUMYUT ${ }^{1}$ (D), Prasert MAKKAEW ${ }^{1}$, Khoihrunhana YADEE ${ }^{1}$, Soraida HLAMCHOOํㅗㄴ, \\ Ifteesan BINYOOSOH ${ }^{1}$, Nopadol PRECHA ${ }^{1 *}$
}

\begin{abstract}
The aim of this descriptive cross-sectional study was to investigate the food safety conditions at food service premises and the hand hygiene of food handlers in Nakhon Si Thammarat, Thailand. The food safety conditions of 24 food service premises in the Pakpoon municipality of Nakhon Si Thammarat were assessed using a food sanitation inspection form and fecal indicator testing. The fecal indicators in this study were coliform bacteria and Escherichia coli (E. coli). A total of 162 samples were randomly collected from food and utensils and analyzed for coliform contamination. Samples were also obtained from food handlers and analyzed for coliform and E. coli contamination. None of the premises achieved the requirements of the Thai food safety standard. The samples showed significant coliform contamination $(p<0.01)$. Notably, the ice and drinking water samples were $100 \%$ coliform positive. The highest number of viable cells of total coliform and $E$. coli on the hands of the food handlers were $>200 \mathrm{CFU} /$ hand and $>50 \mathrm{CFU} /$ hand, respectively. Food safety conditions and food handlers' hand hygiene should be improved to protect consumers from the risk of foodborne diseases.
\end{abstract}

Keywords: coliform, Escherichia coli, food safety, food service, hygiene, food safety survey.

Practical Application: Improving the food safety conditions of food service premises to reduce foodborne diseases.

\section{Introduction}

Food safety is a global public health priority because $10 \%$ of people worldwide get sick from foodborne diseases. More than 400,000 people die each year (World Health Organization, 2021) as a result of consuming food contaminated with bacteria, viruses, parasites, and toxic chemicals. Diarrhea is a common health issue caused by the consumption of food and water contaminated with pathogens such as Salmonella spp., Campylobacter spp., and enterohaemorrhagic Escherichia coli (Centers for Disease Control and Prevention, 2013; World Health Organization, 2021). While most foodborne diseases are caused by the improper preparation or mishandling of food at home, food service premises, or markets, the CDC reported that $50 \%$ of foodborne disease cases were associated with food consumption at food premises and noted that food service premises are an important source of foodborne diseases in humans (Gould et al., 2013).

The Department of Disease Control in Thailand reported diarrhea among 716,513 patients (1,095.21 per 100,000 inhabitants) from January to September 2019 (Epidemiology Division, 2019). Several strategies to improve food safety standards have been established in Thailand, among which the Clean Food Good Taste (CFGT) project is one of the most prominent. The CFGT was implemented in 1999 to support tourism, the local economy, and public health (Bureau of Food and Water Sanitation, 2020). Food hygiene at tourism attractions was highlighted as an essential area of focus in the Second National Tourism Development Plan of Thailand (2017-2021) (The National Tourism Policy Committee, 2017). A CFGT certificate is issued by the BFWS, Department of Health, Ministry of Public Health, following the successful assessment of food service premises. A food sanitation inspection (FSI) form together with microbial indicators for fecal contamination testing are the main tools for food safety surveillance in Thailand (Bureau of Food and Water Sanitation, 2013a). The CFGT annual report by the BFWS in 2018 showed that, while $85.3 \%$ of food service premises achieved the required standard, the number of patients with diarrhea remained high (Bureau of Food and Water Sanitation, 2018). Several factors are involved in preventing foodborne diseases, from poor food safety to the personal hygiene of consumers and food handlers (Kibret \& Abera, 2012; Wambui et al., 2017).

The southern part of Thailand is composed of 14 provinces and is considered outstanding for its tourist attractions and the variety of food on offer. Nakhon Si Thammarat (NST) is the most popular province in the southern part of Thailand. According to the CFGT report in 2018, the NST achieved the lowest percentage for Thai food safety standards in the south (Bureau of Food and Water Sanitation, 2018) In the same year, the diarrhea morbidity rate in NST was 5,991.8 people per 100,000 inhabitants (Health Data Center, 2020). This is concerning because food safety is 
a significant requirement to build consumer confidence and protect the health of consumers (Suphaphon \& Agmapisarn, 2019). Pakpoon municipality is one of the significant areas in the Mueang Nakhon Si Thammarat District, which is the capital district and commercial and economic center of NST. In addition to being a transportation route and tourist stopover, Pakpoon municipality is the location of various important facilities, such as an airport, high schools, military camps, and attractive tourist venues. Notably, Pakpoon municipality has many food service businesses, ranging from large food premises to street food stalls.

Food safety is important for foodborne disease prevention and control and to build confidence in food safety measures among consumers, tourists, and the general population (Aksoydan, 2007; Kibret \& Abera, 2012). This study therefore aimed to investigate the food safety conditions at food service premises and the hand hygiene of food handlers in Pakpoon municipality, Nakhon Si Thammarat, Thailand, to help reduce health risks from foodborne diseases.

\section{Materials and methods}

\subsection{Study area}

The study was conducted in the Pakpoon municipality, which is one of the important subdistricts of Mueang Nakhon Si Thammarat District (Figure 1). In 2016-2020, the diarrhea morbidity rate of Pakpoon municipality was the highest among the subdistricts in Mueang Nakhon Si Thammarat District.

\subsection{Study participants}

This descriptive cross-sectional study was conducted at food service premises in Pakpoon municipality from August to October 2018. All the food service premises $(n=24)$ registered with the local authority in Pakpoon municipality were included in this study, while other types of food services, such as food delivery services and food stalls, were excluded. Registered food service premises that were in the process of renewing their permits were also included. Purposive sampling was applied, and samples were collected from food handlers, food, and kitchen utensils for fecal indicator testing.

\subsection{Food safety survey}

The survey was performed in line with the CFGT standard, which consists of two components: (1) a food sanitation inspection using the FSI form and (2) coliform bacterial testing of food, utensils, and food handlers' hands using the coliform bacteria screening kit (SI-2) developed by the Research and Laboratory Development Center, Department of Health, Thailand. The food handlers' hands were also enumerated for Escherichia coli (E. coli) using 3M" Petrifilm" E. coli/Coliforms Count (EC) Plates (Canada), which is an additional test included in the CFGT

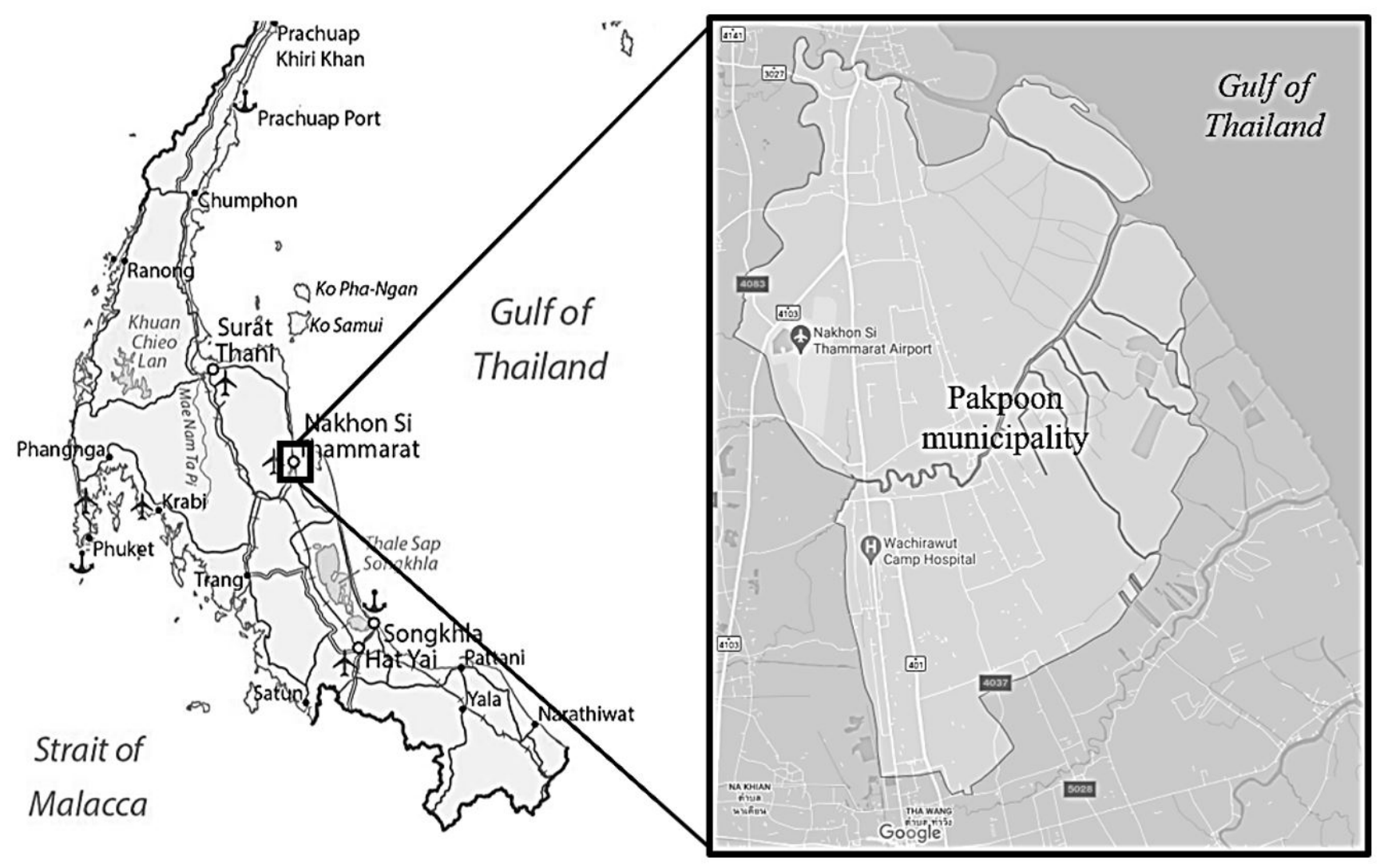

Figure 1. The study area (GISGeography, 2021; Google, 2021). 
standard. The survey was conducted by researchers and assistant researchers who had received training on the survey and microbial analysis techniques.

\subsection{Food sanitation inspection}

The FSI form consists of five categories, namely, (1) preparation and cooking area, (2) food, (3) utensils, (4) sanitation, and (5) food handlers, with 15 criteria in total. Using the BFWS criteria, the food service premises assessment results were categorized as "satisfactory," "unsatisfactory," and "no activity" (Bureau of Food and Water Sanitation, 2013a).

\subsection{Coliform bacterial testing}

The food, utensils, and food handlers were examined for coliform contamination. The coliform bacteria from the three sample types were analyzed using the SI-2 in accordance with the manufacturer's instructions. The sampling protocol was performed by following the BFWS guidelines and included five food samples, three utensil samples, and two food handler samples (chef and waiter) from each premises. The samples were collected by quota sampling. The surfaces of the utensils and the food handlers' hands were swabbed for fecal indicator testing using a sterile cotton swab and an aseptic technique, while the food samples were mixed directly with the SI-2 (Bureau of Food and Water Sanitation, 2013a).

\subsection{Isolation and enumeration of E. coli}

To swab the food handlers' hands for E. Coli, a sterile cotton swab was applied using an aseptic technique. The cotton swab was then placed in a $10 \mathrm{~mL}$ sterile buffer tube, and the screw cap was closed tightly (Bureau of Quality and Safety of Food, 2017). The tube was gently shaken for 30 seconds, and $1 \mathrm{~mL}$ of buffer was pipetted to the EC plates (3M" Petrifilm", Canada) according to the manufacturer's instructions for fecal bacteria detection. The blue colonies with gas were measured and recorded as $E$. coli positive at room temperature $\left(25-37^{\circ} \mathrm{C}\right)$ for $17-24$ hours.

\subsection{Data analysis}

The inspection data and fecal indicator testing were analyzed using descriptive statistics (frequency and percentage). The association between the types of samples, food service premises, roles of the food handlers, and bacterial contamination were analyzed using a chi-square $\left(\chi^{2}\right)$ test with a $95 \%$ confidence level $(\alpha<0.05)$.

\subsection{Ethics statement}

Ethical approval for this study was obtained from the Walailak University Ethics Committee (WUEC-19-207-01). Informed consent were obtained from the participants before collecting the data. The research procedures complied with the EC standard of Walailak University.

\section{Results}

\subsection{Food sanitation inspection}

Twenty-four food service premises in Pakpoon municipality, Nakhon Si Thammarat, Thailand, were included in this study, among them, 16 (66.7\%) savory food premises (cooked-to-order, curry, and ready-to-eat premises) and eight (33.3\%) sweet and beverage premises. The food service premises in the study met the requirements of nine of the 15 criteria (Table 1). However, the BFWS standard indicates that the assessment results should be satisfactory for all the criteria of the food sanitation inspection. Six premises (four savory food premises and two sweet and beverage premises) were found to be unsatisfactory. Although they met the criteria for all utensils, the toilet facilities in these premises were the most critical issue as they lacked sinks and soap for handwashing. The food additives used in all the food service premises had been certified by the Food and Drug Administration, Ministry of Public Health, Thailand. The fresh and cooked foods also met the standard, which requires suitable washing and storage facilities. In total, 18 premises (75\%) achieved the required standards of the food sanitation inspection.

\subsection{Coliform bacterial testing}

In total, 70 (39.6\%), 65 (36.7\%), and 42 (23.7\%) food, utensil, and food handler samples, respectively, were collected for coliform bacterial testing using the SI-2. The amount of each sample type obtained was determined by its availability and the context of the food service premises. Overall, the results of the coliform bacterial testing showed that the utensils had the highest negative results, followed by the food handler and food samples (Table 2). The highest rate of contamination was found in the ice and drinking water samples, which showed $100 \%$ positive results (Figure 2A). The results indicated that none of the food service premises had satisfactory levels of hygiene with respect to coliform contamination because $10 \%$ of the samples at each premises exceeded the CFGT standard. Accordingly, none of the premises achieved the CFGT standard for certification.

\subsection{E. coli enumeration of the food handlers}

Twenty-eight food handlers' hands which obtained positive results of SI- 2 were assessed for $E$. coli contamination. The samples from two food handlers from savory food premises and two from sweet and beverage premises showed blue colonies with gas on the EC plates. E. coli was detected on $14.3 \%(4 / 28)$ of the food handlers' hands, accounting for $16.7 \%$ of all the chefs and $10 \%$ of all the waiters. The E. coli counts on the EC plates were 1-50 (5.6\%) and 51-100 (11.1\%) CFU/hand for the chefs and $1-50 \mathrm{CFU} /$ hand $(10.0 \%)$ for the waiters (Figure $2 \mathrm{~B}$ ).

\subsection{Relationship between the sample types and coliform}

The associations between the sample types, food service premises, roles of the food handlers, and bacterial contamination were analyzed using a chi-square $\left(\chi^{2}\right)$ test with a $95 \%$ confidence interval. The results showed that food, utensils, and food handlers 
Table 1. Results of the food sanitation inspection using the food sanitation inspection form $(\mathrm{n}=24)$.

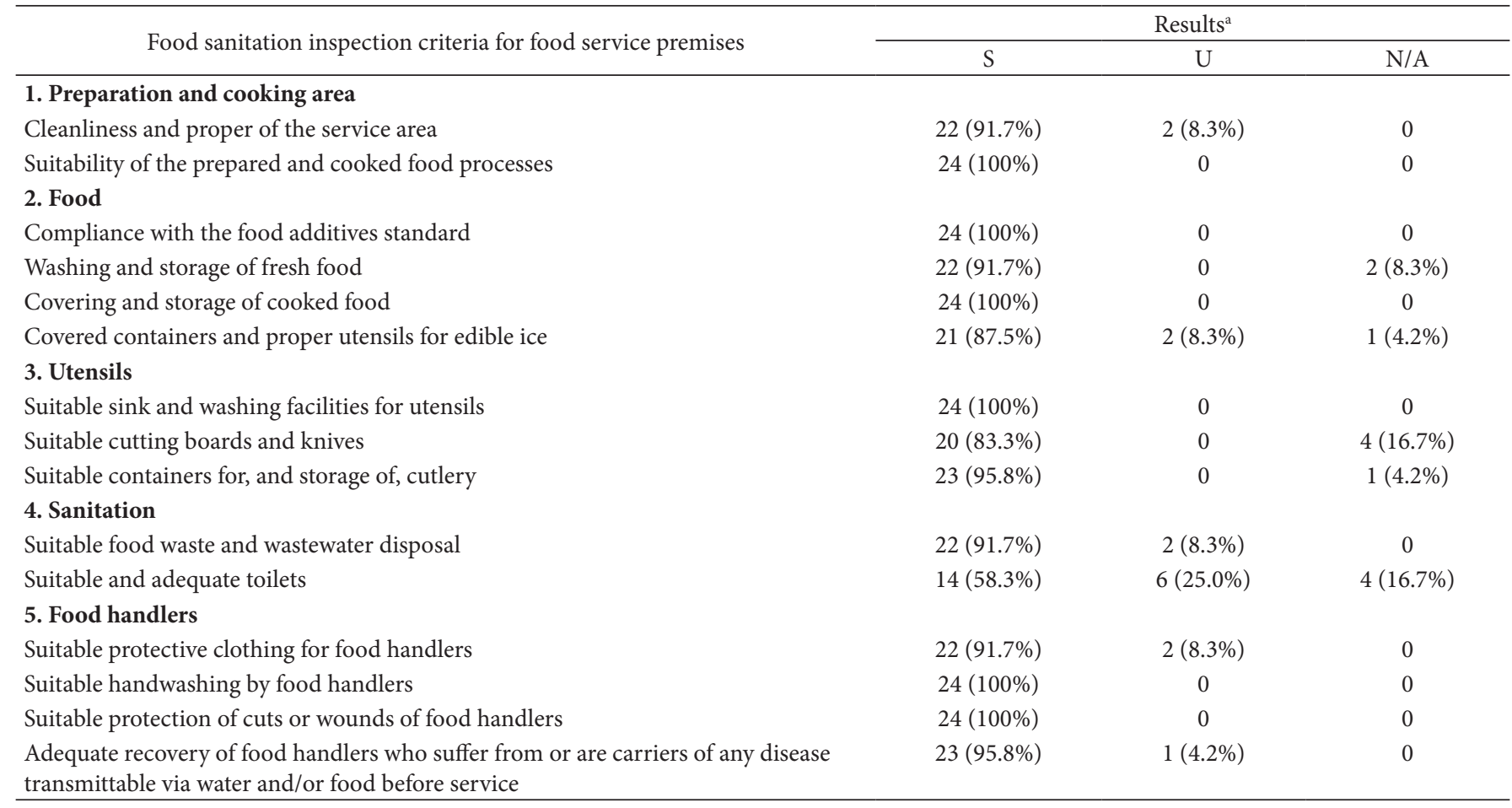

${ }^{a}$ The results indicate the percentages calculated from 24 food service premises. N/A, no activity; S, satisfactory; U, unsatisfactory.

Table 2. The relationships between the sample types and the roles of the food handlers and the coliform bacteria results calculated using a chisquare $(\chi 2)$ test.

\begin{tabular}{|c|c|c|c|}
\hline \multirow{2}{*}{ Variables } & \multicolumn{2}{|c|}{ Number with contamination (\%) } & \multirow{2}{*}{ p-value } \\
\hline & Positive & Negative & \\
\hline \multicolumn{4}{|l|}{ Sample types } \\
\hline Food $(\mathrm{n}=70)^{\mathrm{a}}$ & $55(78.6 \%)$ & $15(21.4 \%)$ & 0.000 \\
\hline Utensils $(\mathrm{n}=65)^{\mathrm{b}}$ & $26(40.0 \%)$ & $39(60.0 \%)$ & \\
\hline Food handlers $(\mathrm{n}=42)^{\mathrm{c}}$ & $29(69.0 \%)$ & $13(31.0 \%)$ & \\
\hline \multicolumn{4}{|l|}{ Food handler roles } \\
\hline Chefs $(\mathrm{n}=24)$ & $18(75.0 \%)$ & $6(25.0 \%)$ & 0.335 \\
\hline Waiters $(\mathrm{n}=18)$ & $11(61.1 \%)$ & $7(38.9 \%)$ & \\
\hline
\end{tabular}

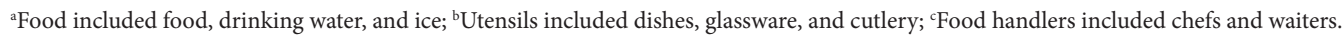

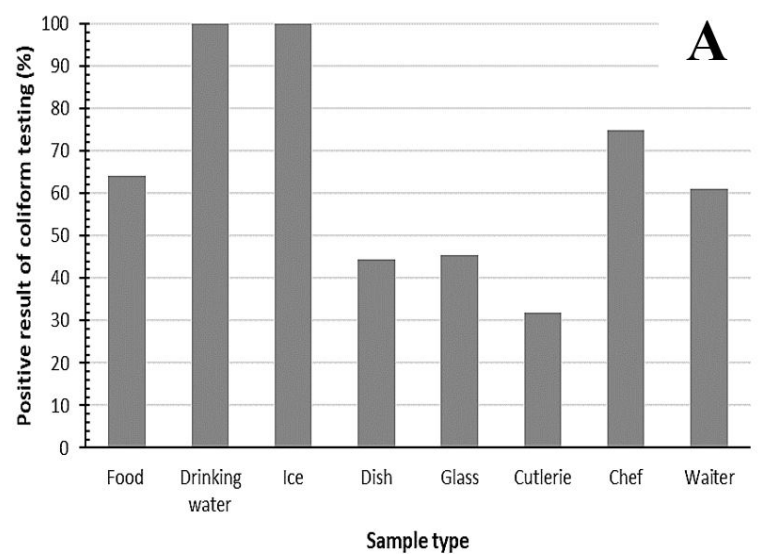

Sample type

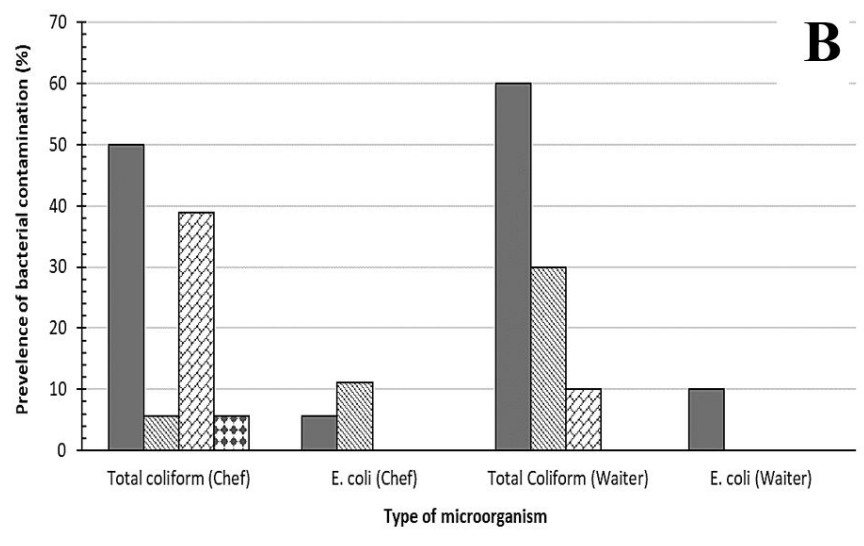

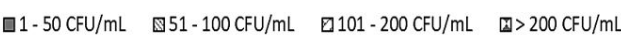

Figure 2. Results of the fecal indicator testing: (A) Positive results of coliform bacterial testing (\%) using the SI-2 of each sample, and (B) the prevalence of coliform and E. coli contamination (CFU/hand) among the chefs and waiters using EC plates $\left(3 \mathrm{M}^{\mathrm{mm}}\right.$ Petrifilm $\left.{ }^{\mathrm{Tm}}\right)(\%)$. 
were significantly associated with coliform bacteria $(p<0.01)$, while the roles of the food handlers were not, as shown in Table 2.

\section{Discussion}

To meet the minimum requirements of the CFGT standard, all the food premises assessed in this study should have complied; however, none of the 24 (100\%) food service premises in the Pakpoon municipality in the study achieved the CFGT standard because the coliform bacteria detection rate exceeded the standard set by the BFWS, Department of Health, Ministry of Public Health, Thailand. This low CFGT achievement rate was similar to that of a study in Phitsanulok province, Thailand, in which a rate of $1.1 \%$ was achieved (Srisai \& Yasaka, 2016). In contrast, the food sanitation inspection in this study was highly satisfactory (up to $75 \%$ ). This finding is consistent with the results of studies in NST and Pattani, which showed high achievement rates of 71.3\% and 64.6\%, respectively (Meewassana et al., 2016; Veerapun \& Thongkum, 2007). Similarly to the present research, these studies also revealed high coliform contamination. Both NST and Pattani are located in the south of Thailand and have a comparably warm climate, so the temperature could contribute to coliform growth. Although the levels of food sanitation at all the premises met the CGFT criteria, the results did not guarantee that all the food, utensils, and food handlers were free of coliform and $E$. coli contamination. Several studies have shown a significant relationship between pathogen contamination and the hygiene of food service premises and cross-contamination (Elson et al., 2004; Gorman et al., 2002; Kibret \& Abera, 2012; Mazengia et al., 2015; Vindigni et al., 2007). To reduce the risk to human health through coliform, E. coli, and other Enterobacteriaceae contamination in food, food sanitation inspections must be carried out and the standards complied with continually.

The critical issues identified in the food sanitation inspection as needing improvement were cleanliness and the appropriateness of the service areas, edible ice, food waste and wastewater management, sanitary facilities in the toilet(s), protective clothing (aprons and hair nets), and disease prevention and control among food handlers. Similar findings were reported by Jongsamak et al. (2014) and Veerapun \& Thongkum (2007), who found that improper utensils were used with edible ice, and other substances such as bottles, vegetables, and raw materials were present in ice containers. The unsanitary disposal systems for solid waste and wastewater account for one-third of the problems in food service premises in many provinces in Thailand. The unsanitary disposal methods identified in this study were uncovered trash and leachate leakage, which could be a breeding site and food source for vectors such as flies and rodents. Unsanitary toilets were also an extensive problem noted during the food sanitation inspections in this study. The same issue was described in the findings of previous studies (Srisai \& Yasaka, 2016; Veerapun \& Thongkum, 2007). The unhygienic conditions of toilets and the lack of sanitary facilities such as toilet paper and soap or alcohol hand sanitizer in toilets could increase the risk of bacterial contamination of food and utensils via food handlers and consumers. Several studies have revealed the prevalence of coliform bacteria and pathogens on the surfaces of toilet facilities, which could be a significant source of foodborne illness transmission from consumers and food handlers' hands to food (Chitpirom, 2013; Nworie et al., 2012). In addition, the food handlers in the present study did not wear hairnets, and their aprons were not clean, so hair and/or microorganisms could be a source of further contamination. Entrepreneurs should therefore perform strict food safety practices in line with the BFWS of Thailand guidelines to prevent adverse health effects on consumers.

Some behaviors and practices that are missing from the FSI form may influence coliform and E. coli contamination. However, the CFGT standard includes both coliform bacterial testing and food sanitation inspections to increase the efficiency of the surveillance system. Coliform bacteria are an important group in the family Enterobacteriaceae and are one of the essential indicators in food sanitation inspections of food service premises. The SI-2 is widely used to screen for coliform bacteria as part of the food safety surveillance in Thailand (Kongpran et al., 2021). The SI-2, which was developed by the Department of Health, Thailand, is the field test kit for screening for coliform in food. The SI-2 medium contains lactose broth with bromocresol purple as an indicator. Theoretically, coliform bacteria can ferment lactose with the production of acid and gas at $35-37^{\circ} \mathrm{C}$ (Patel et al., 2014). The acidification of the medium causes the $\mathrm{pH}$ indicator bromocresol purple to change the color of the medium from purple to yellow, which indicates the presence of coliform. This test kit shows high efficiency, is inexpensive, and produces results for interpretation quickly (Bureau of Food and Water Sanitation, 2013b).

In this study, the highest coliform bacteria contamination was detected in food, followed by food handlers and utensils. Cross-contamination from food handlers and utensils leads to coliform contamination in food (Gorman et al., 2002; Mazengia et al., 2015). Edible ice and drinking water had the highest rate (100\%) of coliform contamination among the food samples in the present study. This finding is similar to those of studies in Nakhon Pathom and Samut Sakhon provinces where the total coliform bacteria detected in ice samples was $100 \%$ and 53.0\%, respectively (Jongsamak et al., 2014; Sirichokchatchawan \& Somrongthong, 2020). Likewise, Yodmanee et al. (2012) found that $92.5 \%$ and $57.5 \%$ of the ice in three provinces in the lower south region of Thailand were contaminated with coliform and E. coli at higher rates than those stipulated in the Notification of the Ministry of Public Health, Edition 78 (1984). The researchers reported that size of edible ice, water quality, ice machines, ice scoops, containers, and food handlers' hygiene affected ice contamination. In the current study, $69 \%$ of the food handlers were found to have coliform contamination on their hands, and $40 \%$ of the utensils were contaminated. A high coliform contamination rate among food handlers in food service premises was also found in previous studies in NST (75.5\%) and Phitsanulok (54.0\% and 61.0\%), with utensil contamination also present in these provinces (NST, 56.3\%; Phitsanulok, 49.0\% and 47.0\%) (Meewassana et al., 2016; Perathornich et al., 2015; Srisai \& Yasaka, 2016).

Although the results of the food sanitation inspections in this study were satisfactory at $66.7 \%$, the tests for coliform bacteria were $100 \%$ positive. Other issues not included in the FSI 
checklist could influence bacterial contamination. For example, the cleanliness of doorknobs and water taps in toilet facilities are not mentioned. Doorknobs and water taps are often ignored during the cleaning of most premises; however, these can become contaminated and result in the accumulation of bacteria, which can be conveyed to the hands of food handlers and consumers through contact with these items (Chitpirom, 2013; Nworie et al., 2012). Another critical issue is towels that are used to wipe hands, dishes, and tables repeatedly without cleaning. Such microorganism contamination could have been present in almost all the food service premises in this study. Previous studies have reported that towels, especially cloth towels, were used multiple times and could accumulate microorganisms, with these microorganisms then spreading to food handlers' hands, utensils, tables, and food-related areas (Cogan et al., 2002; Gerba et al., 2014; Sneed et al., 2015). Gerba et al. (2014) recommended that towels be washed often as this could significantly reduce the amount of $E$. coli present.

The total coliform numbers on food handlers' hands were satisfactory based on the microbiology criteria of food handlers in Thailand, which indicate that total coliform on food handler's hands must be less than $500 \mathrm{CFU} /$ hand. Notwithstanding, the Thai food safety standard states that $E$. coli must not be detected on food handlers' hands (Bureau of Quality and Safety of Food, 2017). In this study, four food handlers were found to have E. coli contamination, so their personal hygiene should be improved to reduce the risk of foodborne diseases.

This study showed that the types of food and utensils were not related to the presence of coliform because coliform was found on all the sample types, especially the edible ice samples. This result is in contrast to the results of a previous study in Thailand, which found a significant difference in coliform contamination among different types of food $(p<0.001)$ (Perathornich et al., 2015). The association analysis in this study found that the roles of food handlers were not related to the prevalence of coliform bacteria, while a significant association was found among food, utensils, and food handlers. Food had the highest risk of contamination because both utensils and food handlers can contaminate food.

\section{Conclusion}

The results of the food sanitation inspections did not relate to coliform contamination. Food was found to have the highest positive rate for coliform compared to utensils and food handlers' hands. Moreover, E. coli was detected on food handlers' hands. Food sanitation measures, as well as the hygiene of food handlers, play an important role in the prevention and control of food-borne diseases.

\section{Acknowledgements}

The authors would like to thank the Environmental Health laboratory staff of Walailak University for their help in this study and the participants for their cooperation in the study.

\section{References}

Aksoydan, E. (2007). Hygiene factors influencing customers' choice of dining-out units: finding from a study of university academic staff. Journal of Food Safety, 27(3), 300-316. http://dx.doi.org/10.1111/ j.1745-4565.2007.00081.x.

Bureau of Food and Water Sanitation. (2013a). Clean food good taste guidelines. Bangkok: The Agricultural Cooperative Federation of Thailand Limited.

Bureau of Food and Water Sanitation. (2013b). Principles of food sanitation inspector. Thailand: Bureau of Food and Water Sanitation.

Bureau of Food and Water Sanitation. (2018). Clean food good taste report. Retrieved from http://foodsan.anamai.moph.go.th/ewt_dl_link. php?nid=2641\&filename $=$ food_index 18

Bureau of Food and Water Sanitation. (2020). Street food good health. Nonthaburi: Department of Health.

Bureau of Quality and Safety of Food. (2017). Quality criteria of microbiology of foods and utensils (Vol. 3). Bangkok: P2 Design \& Print Company Limited.

Centers for Disease Control and Prevention - CDC. (2013). Diarrhea: common illness, global killer. Atlanta: CDC.

Chitpirom, K. (2013). Evaluation and bacterial contamination of public toilets. KKU Science Journal Volume, 41(3), 789-796.

Cogan, T. A., Slader, J., Bloomfield, S. F., \& Humphrey, T. J. (2002). Achieving hygiene in the domestic kitchen: the effectiveness of commonly used cleaning procedures. Journal of Applied Microbiology, 92(5), 885-892. http://dx.doi.org/10.1046/j.1365-2672.2002.01598.x. PMid:11972693.

Elson, R., Burgess, F., Little, C. L., \& Mitchell, R. T., \& Local Authorities Co-Ordinators of Regulatory Services and the Health Protection Agency (2004). Microbiological examination of ready-to-eat cold sliced meats and pâté from catering and retail premises in the UK. Journal of Applied Microbiology, 96(3), 499-509. http://dx.doi. org/10.1111/j.1365-2672.2004.02203.x. PMid:14962130.

Epidemiology Division. (2019). Diarrhea situation in Thailand. Bangkok: Epidemiology Division.

Gerba, C. P., Tamimi, A. H., Maxwell, S., Sifuentes, L. Y., Hoffman, D. R., \& Koenig, D. W. (2014). Bacterial occurrence in kitchen hand towels. Food Protection Trends, 34(5), 312-317.

GISGeography. (2021). Map of Thailand. Retrieved from https:// gisgeography.com/thailand-map/

Google. (2021). Pak Phun. Retrieved from https://www.google.co.th/ maps/place/Pak+Phun,+Mueang+Nakhon+Si+Thammarat+Dist rict,+Nakhon+Si+Thammarat/@8.5246413,99.870793,11z/data=! $4 \mathrm{~m} 5$ !3m4!1s0x3053061c2789ee8d:0x40223bc2c3813f0!8m2!3d8.5 200209 !4d99.9766331?hl=en

Gorman, R., Bloomfield, S., \& Adley, C. C. (2002). A study of crosscontamination of food-borne pathogens in the domestic kitchen in the Republic of Ireland. International Journal of Food Microbiology, 76(1-2), 143-150. http://dx.doi.org/10.1016/S0168-1605(02)000284. PMid:12038571.

Gould, L. H., Rosenblum, I., Nicholas, D., Phan, Q., \& Jones, T. F. (2013). Contributing factors in restaurant-Associated foodborne disease outbreaks, foodnet sites, 2006 and 2007. Journal of Food Protection, 76(11), 1824-1828. http://dx.doi.org/10.4315/0362-028X. JFP-13-037. PMid:24215683.

Health Data Center. (2020). Diarrhea morbidity rate. Retrieved from https://hdcservice.moph.go.th/hdc/reports/report.php?source=formated/ format_2.php\&cat_id=7f9ab56b0f39fd053143ecc4f05354fc\&id $=30$ 9e77ea6f4c09faa9bcf75a8c9aee13 
Jongsamak, P., Charoenteeraboon, J., \& Techaarpornkul, S. (2014). A Microbial Safety Survey of Edible at Cafeterias and a Weekly Market of Silpakorn University, Sanamchandra Palace. Thai Bulletin of Pharmaceutical Sciences, 9(1), 14-23.

Kibret, M., \& Abera, B. (2012). The sanitary conditions of food service establishments and food safety knowledge and practices of food handlers in Bahir Dar town. Ethiopian Journal of Health Sciences, 22(1), 27-35. PMid:22984329.

Kongpran, J., Thanapop, C., \& Vattanasit, U. (2021). Environmental sanitation and hygiene of elderly workers in Nakhon Si Thammarat Province, Thailand. Journal of Preventive Medicine and Hygiene, 62(1), E152-E163. PMid:34322631.

Mazengia, E., Fisk, C., Liao, G., Huang, H., \& Meschke, J. (2015). Direct observational study of the risk of cross-contamination during raw poultry handling: practices in private homes. Food Protection Trends, 35(1), 8-23.

Meewassana, S., Thirarattanasunthon, P., \& Kotepui, M. (2016). Food sanitation condition assessment in Nakhon Si Thammarat province: A case study in camp Vajiravudh and restaurants. Environmental Health, 18(2), 50-65.

Nworie, A., Ayeni, J., Eze, U., \& Azi, S. (2012). Bacterial contamination of door handles/knobs in selected public conveniences in Abuja metropolis, Nigeria: a public health threat. Continental Journal of Medical Research, 6(1), 7-11.

Patel, A. K., Singhania, R. R., Pandey, A., Joshi, V. K., Nigam, P. S., \& Soccol, C. R. (2014). Enterobacteriaceae, Coliforms and E. Coli: introduction. In C. A. Batt \& M. L. Tortorello (Eds.), Encyclopedia of food microbiology (2nd ed., Vol. 1, pp. 659-666). London: Elsevier. http://dx.doi.org/10.1016/B978-0-12-384730-0.00096-3.

Perathornich, T., Sujirarat, D., \& Sreesai, S. (2015). The analysis of factors influencing food sanitation in Phitsanulok municipality, Phitsanulok province. Journal of Public Health, 45(3), 230-243.

Sirichokchatchawan, W., \& Somrongthong, R. (2020). Microbiological contamination in restaurants and food hygiene practices among migrant food handlers in Samut Sakhon province, Thailand. Food Protection Trends, 40(2), 101-110.

Sneed, J., Phebus, R., \& Duncan-Goldsmith, D. (2015). Consumer food handling practic. Food Protection Trends, 35(1), 36-48.

Srisai, Y., \& Yasaka, S. (2016). Situation of food sanitation in the area around Naresuan University Phitsanulok Province Thailand. Disease Control Journal, 42, 327-336.

Suphaphon, W., \& Agmapisarn, C. (2019). Food-quality factors and attitudes that influence inbound tourist's perception of street food safety. Case study: Khao San Road, Bangkok. WMS Journal of Management, 8(1), 10-23.

The National Tourism Policy Committee. (2017). The second national tourism development plan (2017-2021) (Vol. 2). Bangkok: The National Tourism Policy Committee.

Veerapun, N., \& Thongkum, P. (2007). Factors affecting food sanitation performance following the standards of food establishments for food shops in Muang district, Pattani province. Songklanakarin Journal of Social Sciences and Humanities, 13(2), 187-200.

Vindigni, S. M., Srijan, A., Wongstitwilairoong, B., Marcus, R., Meek, J., Riley, P. L., \& Mason, C. (2007). Prevalence of foodborne microorganisms in retail foods in Thailand. Foodborne Pathogens and Disease, 4(2), 208-215. http://dx.doi.org/10.1089/fpd.2006.0077. PMid:17600488.

Wambui, J., Karuri, E., Lamuka, P., \& Matofari, J. (2017). Good hygiene practices among meat handlers in small and medium enterprise slaughterhouses in Kenya. Food Control, 81, 34-39. http://dx.doi. org/10.1016/j.foodcont.2017.05.036.

World Health Organization - WHO. (2021). Food safety. Retrieved from https://www.who.int/NEWS-ROOM/FACT-SHEETS/DETAIL/ FOOD-SAFETY

Yodmanee, S., Cheloh, S., Kalupae, P., \& Pakdeechanuan, P. (2012). Analysis of microbiological safety of ice in Pattani, Yala and Narathiwat. Journal of Yala Rajabhat University, 7(1), 24-34. 